\title{
Information Practices and Digital Perspectives of Municipal Waste Recovery Providers in Europe
}

\author{
Ljerka Luić*, Krešimir Labura
}

\begin{abstract}
The priority of modern business systems of municipal waste management is recycling of waste materials while the imperative of their mission is determined by the degree of digital transformation which enables their reproduction, distribution, usage, and storage of information in digital form, as well as new ways of digital communication with the general public. In this paper the focus is on examining the information practices and digital perspectives of municipal waste recycling service providers in Europe. The goal of this paper was to detect information concepts relevant for establishing the degree of their digital maturity. Five data classes were created for the purpose of content analysis method to conduct research on practices on digital communication channels in seven countries to evaluate their availability and accuracy. The designed information model defines a unique conceptual framework of the digital communication information set of the municipal waste recycling service providers.
\end{abstract}

Keywords: digital communication; digital transformation; Europe; information model; recycling; waste recovery

\section{INTRODUCTION}

Digital media and technologies play a key role in shaping society's perception of waste management. [1] They have the ability to influence public opinion and change public awareness, making it a powerful tool which can persuade the public to take action. [2] In this paper, by applying the research method of content analysis, it is considered and determined how utility companies communicate the waste recycling message to the public. Waste management is certainly one of the most important issues of civilization, but also an increasingly important economic issue, especially in the sense of conservation of natural resources and management of environmental protection costs. [3, 4] The priority in modern waste management systems is the recycling of waste materials. Most European countries have implemented regulations in their legislation that aim to reduce the amount of municipal waste and increase the amount of usable waste.

\subsection{Material Recycling of Municipal Waste}

According to the Law on Sustainable Waste Management (Article 4, para. 35), the term waste is any substance or object that the holder discards, intends or must discard. Waste is also considered to be any object and substance whose collection, transport or treatment is necessary for the purpose of protecting the public interest. [5]

Municipal waste is just one of the types of waste that requires enormous efforts in researching technologies (material, energy, chemical recycling), access and information, in order to drastically reduce the share of its production. However, much can be done by an individual, so through informing it is possible to acquire new knowledge and aid technology in reducing waste production. Materials recovery (recycling) is just one of the ways in which a new purpose is given to municipal waste either through the production of new products, compost, or biofuels.

Waste recovery is defined by the Law on Sustainable Waste Management (Article 4, para. 34) as "any operation whose main result is the use of waste for useful purposes when waste replaces other materials which should otherwise be used for that purpose or waste prepared to meet that purpose, in the factory or in a broader economic sense". [5]

Hrnjak-Murgić [6] distinguishes three types of recovery: Energy recovery, Chemical recovery and Material recovery.

Energy recovery or energy recycling essentially means the incineration of waste, which is the process of exposing waste to heat, resulting in the release of heat and the products of complete or incomplete combustion. The released heat can be used to heat water or to produce electricity in power plants. In this type of waste treatment, it is extremely important to pay attention to the controls of the combustion process and the substances that go into the air and water. [6]

Chemical recovery, chemical recycling or chemical reclamation is the process of converting waste into a raw material in which molecular changes, changes in the shape and function of the primary product occur. This type of waste recovery requires prior preparation (such as cleaning, sterilization, etc.), which is why the costs of this type of recovery are extremely high, and to make the approach more economical, large quantities and an organized waste collection system are needed. [6]

Material recovery of waste is defined by The Law on Sustainable Waste Management (Article 4, para. 20) as "any recovery process that does not include energy recovery and processing into materials to be used as fuel". This method of waste treatment is the best known and simplest form, and the purpose is to reduce the use of natural resources, reduce the production of new waste and protect the environment. The terms material reclamation or material recycling are often used for material recovery. [5]

As a general rule, in this type of recovery the waste goes through a treatment process, and in the end the result is a new product or the basis for a new product.

Municipal waste can be found at practically every step of modern society and presents one of the main problems, which is why it is extremely important to bring closer and simplify information approaches to the extent where examples of good practice in municipal waste management are understandable to all ages through the availability of information through 
websites, social networks and other communication channels, especially digital ones. $[7,8]$

\subsection{Digital Communication}

Digital communication greatly helps to establish and maintain communication between a business organization and its public and enables fast access to data and transmission of relevant information to the target public. [9]

More recently, the term digital is gaining a meaning that refers not only to the technological aspect, but also to a new way of communication and culture of society. [10]

The construction of a global information infrastructure has led to the globalization of information systems, which is reflected in the use of computers in everyday life and work, communication using computers and an increasing amount of available information. All this leads to the competitiveness of media content producers and their constant adaptation to new conditions and needs of users. The content produced nowadays are mainly created in digital form, and those created in analogue form are also transferred to digital form and are further processed, distributed, and stored digitally. [11]

Technological development has brought changes in all areas of people's lives, including communications. The fact is that technology has changed the way information is accessed and the way we communicate. [12] With the emergence of the Internet, communication takes on a new dimension, becoming two-way, while allowing each participant to be a user (consumer) and / or content creator.

According to Tomić, "Digital communication is a way of connecting, sharing, and exchanging information between people via the Internet or connected devices using one of the communication tools such as e-mail, forums, chats, instant messages, blogs, websites, and contact forms on them and, more recently, social networks and services". [13]

What distinguishes digital communication from previous modes of communication is virtuality, mobility, high interactivity, high connectivity, multimediality and new media. [14, 15] The basic characteristic of digital communication is the fact that we receive, or send, information now and receive real-time feedback.

"Croatia must take the necessary measures to increase preparation for the reuse and recycling of municipal waste to at least $50 \%$ by $2025,55 \%$ by 2030 and $60 \%$ by 2035 ." [16] In addition to the state, local government units and citizens, utilities companies in particular have a major role to play in achieving these goals. Waste management and informing the public how to properly recycle is of great importance for the sustainable development of society, where digital technologies and digital forms of communication can significantly contribute to achieving the goals related to waste reduction. [17]

\subsection{Information Practices and Digital Communication Perspectives of Material Recovery of Municipal Waste}

The research part of this paper is an interdisciplinary symbiosis of ecology, mechanical engineering, information science and communications studies, which is evident from the matrix of observed data shown in Tab.1.
The field of mechanical engineering is represented in a deliberate sample consisting of business entities whose production takes place primarily in the field of mechanical engineering. The field of ecology is also represented in a deliberate sample of companies whose activity is the material recovery of municipal waste, while the part related to the field of information and communication sciences is represented through research of digital communications and analysis of available data on social networks, applications, and digital platforms for each individual business entity.

The analysis was conducted by first defining the data classes to be researched, and then the main categories of digital communication channels, shown in columns in Tab. 1, which make up social networks, applications, and platforms. Data significant for business entities whose activity is the material recovery of municipal waste are listed in the rows of Tab. 1.

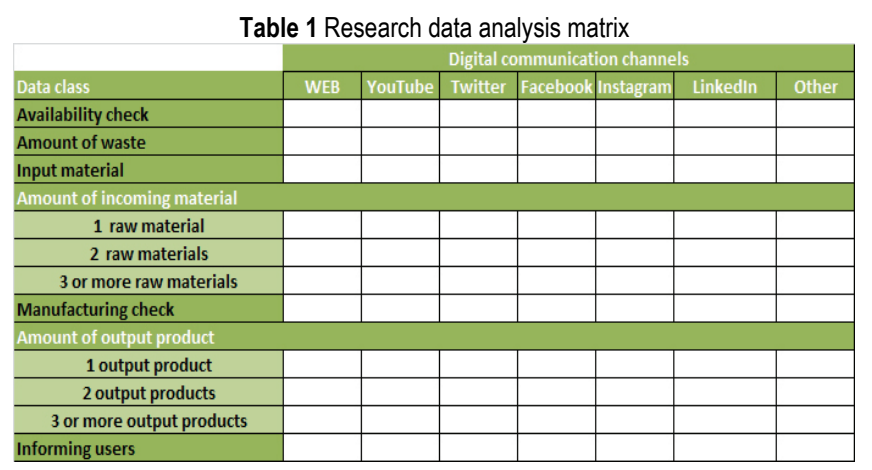

As can be seen from Tab. 1, the initial row of the analysis matrix is defined by the name Digital Communication Channels and contains fields for entering the results of available data via the Internet for each individual business entity, in the following order:

- Business entity's website

- YouTube

- Twitter

- Facebook

- Instagram

- LinkedIn

- Other.

The initial column is defined by the name Data class and the following categories:

- Availability Check

- Amount of waste

- Input material

- Amount of incoming material

- Manufacturing check

- Amount of output product

- Informing users.

\section{METHODOLOGY}

The research was conducted on a sample of business entities whose activity is the material recovery of municipal waste, provided that the same entities manufacture at least 
one product or semi-product. Furthermore, the selection of business entities was followed by an analysis of the data based on the verification of each individual data category listed in the matrix column shown in Tab. 1 under the Data Class category. The research was conducted by the method of digital content analysis during the 4th quarter of 2019. In addition to Croatia and the neighbouring country of Bosnia and Herzegovina, the analysis was conducted on 5 other European Union countries. The criterion for selecting the European Union country was the percentage of the amount of recycled municipal waste, from the best to the worst result. According to Eurostat data, shown in Tab. 2 [18], it can be seen that the following countries have the highest rate of municipal waste recycling:

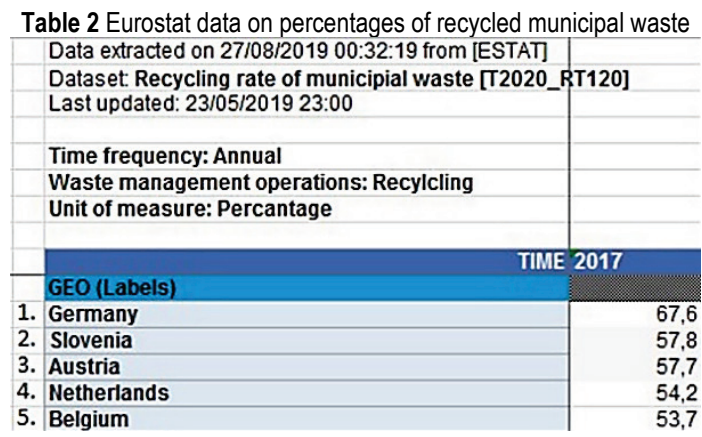

Based on the analysis of relevant sources, it was concluded that only one type of municipal waste should be processed. Recognizing environmental trends and related digital communication, the research is focused on the analysis of plastic waste.

According to the "ENF Recycling" register [19], in the category of plants for the processing of plastics from municipal waste, there are the following number of business entities that materially recover waste:

1) Germany -138 business entities [20]

2) Slovenia - 4 business entities [21]

3) Austria - 14 business entities [22]

4) Netherlands - 30 business entities [23]

5) Belgium - 10 business entities. [24]

Finally, up to five business entities whose activity is the processing of plastics from municipal waste were randomly selected for each of the countries. Consequently, the subject of the research was to investigate the application of digital communication channels in utility companies whose activity is the material recovery of municipal waste. The aim of this paper is to determine the degree of availability of information in these companies through available digital communication channels, based on which the hypothesis is set which claims that the level of digital communication of utility companies in Croatia is lower than the level of digital communication of utility companies in the observed countries.

\section{RESULTS}

Data analysis was performed on information objects of the Data Class category, shown in Tab. 1, according to the following validation elements:
- Availability check - analysis of this data implies the existence of a specific communication channel. If the result of the analysis was negative for a particular communication channel, it means that it does not even exist, which is why the other observed segment is also negative.

- Amount of waste - analysis of availability of data related to the amount of treated waste expressed in tons per year for each digital communication channel.

- Input material - analysis of this data means determining the availability of data on input raw materials for each individual digital communication channel. In case of a positive result of the analysis, an additional analysis of the amount of input raw materials was performed.

- Amount of incoming material - in the case where the Input material feature is confirmed, the quantity of input raw materials is analysed. This category is divided into three subcategories which define the data on the amount of input raw materials listed on each communication channel. The subcategories are defined as follows: One, Two, Three or more input raw materials.

- Manufacturing check - the analysis of this data determines the availability of data on the production of a new product. If the result of the analysis is positive, the next step is to determine the available data on the Amount of output product.

- Amount of output product - concerning criteria, the category is the same as the Amount of incoming material, with the difference of another target source of observation. Therefore, if the result of the Manufacturing check analysis is positive, the quantity of raw materials is investigated. This category is divided into three subcategories which are defined as follows: One, Two, Three or more output products.

- Informing users - the analysis of this category determines the availability of data whose purpose is to inform users as a form of a wide range positive practice, from informing in the field of general knowledge to detailed technical data.

The criteria for the minimum evaluation of data are defined depending on the purpose of each segment from the category Digital communication channels:

- YouTube - accepted cases are the ones in which the

business entity is described by a third party, but with all the details related to the business entity. For example, a report by a TV company about a business entity with a conversation between representatives.

- Twitter - keywords that include details of the name of the business entity during which it can be unambiguously determined to be the same are evaluated.

- Facebook - the available information is evaluated regardless of the form (personal profile or page) with an emphasis on the possibility of unambiguously determining the details of the business entity.

- Instagram - company profiles or posts described by a third party that could unambiguously establish a link between the business entity and the topic of this paper were evaluated.

- LinkedIn - given the possibilities and purpose of the social network, the results of the analysis which were 
allegations of the individual in which they have a connection with the business entity were excluded.

- Other - in this category, the available data of video recordings were observed (for example, Vimeo recordings for business entities and their content).

It is important to emphasize that this approach analysed the availability of data via the Internet and in the case of a negative result does not necessarily mean that the same data does not exist somewhere, but only that for analysis purposes it was not available within the observed criteria.

The following subchapters present the results of the analysis for business entities whose nature of business is the material recovery of municipal waste.

\subsection{Croatia}

The analysis on the example of Croatia was performed on four available business entities. Tab. 3 shows that in Croatia Twitter, Instagram and LinkedIn are not used as a means of information by business entities, while websites (75\%), YouTube (25\%), Facebook (25\%) and Other (25\%) are used.

\begin{tabular}{|c|c|c|c|c|c|c|c|}
\hline \multirow[b]{2}{*}{ Data class } & \multicolumn{7}{|c|}{ Digital communication channels } \\
\hline & WEB & YouTube & Twitter & Facebook & Instagram & Linkedin & Other \\
\hline Availability check & $75 \%$ & $25 \%$ & $0 \%$ & $25 \%$ & $0 \%$ & $0 \%$ & $25 \%$ \\
\hline Amount of waste & $0 \%$ & $25 \%$ & $0 \%$ & $0 \%$ & $0 \%$ & $0 \%$ & $0 \%$ \\
\hline Input material & $75 \%$ & $0 \%$ & $0 \%$ & $0 \%$ & $0 \%$ & $0 \%$ & $25 \%$ \\
\hline \multicolumn{8}{|l|}{ Amount of incoming material } \\
\hline 1 raw material & $25 \%$ & $0 \%$ & $0 \%$ & $0 \%$ & $0 \%$ & $0 \%$ & $0 \%$ \\
\hline 2 raw materials & $0 \%$ & $0 \%$ & $0 \%$ & $0 \%$ & $0 \%$ & $0 \%$ & $0 \%$ \\
\hline 3 or more raw materials & $50 \%$ & $0 \%$ & $0 \%$ & $0 \%$ & $0 \%$ & $0 \%$ & $25 \%$ \\
\hline Manufacturing check & $75 \%$ & $25 \%$ & $0 \%$ & $25 \%$ & $0 \%$ & $0 \%$ & $25 \%$ \\
\hline \multicolumn{8}{|l|}{ Amount of output product } \\
\hline 1 output product & $25 \%$ & $0 \%$ & $0 \%$ & $25 \%$ & $0 \%$ & $0 \%$ & $0 \%$ \\
\hline 2 output products & $0 \%$ & $25 \%$ & $0 \%$ & $0 \%$ & $0 \%$ & $0 \%$ & $0 \%$ \\
\hline 3 or more output products & $50 \%$ & $0 \%$ & $0 \%$ & $0 \%$ & $0 \%$ & $0 \%$ & $25 \%$ \\
\hline Informing users & $75 \%$ & $0 \%$ & $0 \%$ & $0 \%$ & $0 \%$ & $0 \%$ & $25 \%$ \\
\hline
\end{tabular}

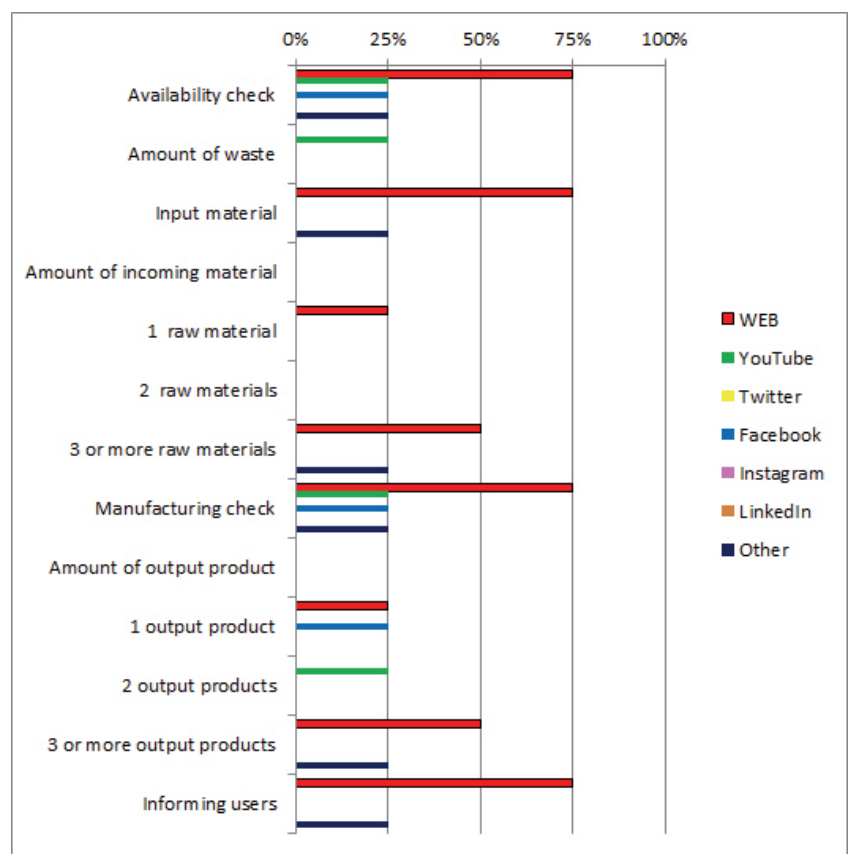

Figure 1 Graphic representation of the analysis results for Croatia
According to the graph shown in Fig. 1, it can be seen that in Croatia business entities most often use the web as a digital communication channel. However, in addition to being the most common, the web is also the most detailed source of information, so information on the Input material and its Amount, on Manufacturing and Amount of output product and Informing users is available on it. Data on Amount of output product is available on YouTube, which confirms the Manufacturing check. Only the data on the Amount of output product is visible on Facebook, which confirms the Manufacturing check.

\subsection{Bosnia and Herzegovina}

In Bosnia and Herzegovina, only one business entity was available and its available data were analysed. Tab. 4 shows that only websites $(100 \%)$ and YouTube $(100 \%)$ were used to inform users, while other communication channels did not give positive results. Although this is $100 \%$ data availability, it is important to emphasize that this is a small number of samples ( 1 business facility). Since this is a single business entity, the results are presented and analysed only in tabular form.

\begin{tabular}{|c|c|c|c|c|c|c|c|}
\hline \multirow[b]{2}{*}{ Data class } & \multicolumn{7}{|c|}{ Digital communication channels } \\
\hline & WEB & YouTube & Twitter & Facebook & Instagram & Linkedln & Other \\
\hline Availability check & $100 \%$ & $100 \%$ & $0 \%$ & $0 \%$ & $0 \%$ & $0 \%$ & $0 \%$ \\
\hline Amount of waste & $100 \%$ & $0 \%$ & $0 \%$ & $0 \%$ & $0 \%$ & $0 \%$ & $0 \%$ \\
\hline Input material & $100 \%$ & $100 \%$ & $0 \%$ & $0 \%$ & $0 \%$ & $0 \%$ & $0 \%$ \\
\hline \multicolumn{8}{|l|}{ Amount of incoming material } \\
\hline 1 raw material & $0 \%$ & $0 \%$ & $0 \%$ & $0 \%$ & $0 \%$ & $0 \%$ & $0 \%$ \\
\hline 2 raw materials & $0 \%$ & $0 \%$ & $0 \%$ & $0 \%$ & $0 \%$ & $0 \%$ & $0 \%$ \\
\hline 3 or more raw materials & $100 \%$ & $100 \%$ & $0 \%$ & $0 \%$ & $0 \%$ & $0 \%$ & $0 \%$ \\
\hline Manufacturing check & $100 \%$ & $100 \%$ & $0 \%$ & $0 \%$ & $0 \%$ & $0 \%$ & $0 \%$ \\
\hline \multicolumn{8}{|l|}{ Amount of output product } \\
\hline 1 output product & $0 \%$ & $100 \%$ & $0 \%$ & $0 \%$ & $0 \%$ & $0 \%$ & $0 \%$ \\
\hline 2 output products & $0 \%$ & $0 \%$ & $0 \%$ & $0 \%$ & $0 \%$ & $0 \%$ & $0 \%$ \\
\hline 3 or more output products & $100 \%$ & $0 \%$ & $0 \%$ & $0 \%$ & $0 \%$ & $0 \%$ & $0 \%$ \\
\hline Informing users & $100 \%$ & $100 \%$ & $0 \%$ & $0 \%$ & $0 \%$ & $0 \%$ & $0 \%$ \\
\hline
\end{tabular}

The website displays details on the Amount of processed waste, Input material and its Amount, confirmed Manufacturing through the Amount of three or more output products and Informing users is available. Unlike the business entity's website, YouTube does not define data on the Amount of processed waste, and there is a difference in the result of the Amount of output product.

The analysis of YouTube could lead to results from One output product, while the results on the website point to Three or more output products. As in the example of the website, data on Input raw materials and Amounts are available on YouTube, Manufacturing check is confirmed by the Amount of output Product, and Informing users is available.

\subsection{Germany}

The analysis of Germany was done on a sample of five randomly selected business entities. Tab. 5 shows that the analysed data are available through almost all digital communication channels in the following order: websites $(100 \%)$, LinkedIn (80\%), YouTube and Twitter $(60 \%)$, Facebook (40\%) and Instagram (20\%). Other digital channels do not have data available. 
Table 5 Results of data analysis for Germany

\begin{tabular}{|c|c|c|c|c|c|c|c|}
\hline \multirow[b]{2}{*}{ Data class } & \multicolumn{7}{|c|}{ Digital communication channels } \\
\hline & WEB & \begin{tabular}{|l|l} 
YouTube \\
\end{tabular} & Twitter & Facebook & Instagram & Linkedln & Other \\
\hline Availability check & $100 \%$ & $60 \%$ & $60 \%$ & $40 \%$ & $20 \%$ & $80 \%$ & $0 \%$ \\
\hline Amount of waste & $60 \%$ & $20 \%$ & $20 \%$ & $20 \%$ & $0 \%$ & $0 \%$ & $0 \%$ \\
\hline Input material & $80 \%$ & $60 \%$ & $20 \%$ & $20 \%$ & $0 \%$ & $0 \%$ & $0 \%$ \\
\hline \multicolumn{8}{|l|}{ Amount of incoming material } \\
\hline 1 raw material & $20 \%$ & $0 \%$ & $0 \%$ & $20 \%$ & $0 \%$ & $0 \%$ & $0 \%$ \\
\hline 2 raw materials & $0 \%$ & $0 \%$ & $0 \%$ & $0 \%$ & $0 \%$ & $0 \%$ & $0 \%$ \\
\hline 3 or more raw materials & $60 \%$ & $60 \%$ & $20 \%$ & $0 \%$ & $0 \%$ & $0 \%$ & $0 \%$ \\
\hline Manufacturing check & $80 \%$ & $60 \%$ & $20 \%$ & $20 \%$ & $0 \%$ & $0 \%$ & $0 \%$ \\
\hline \multicolumn{8}{|l|}{ Amount of output product } \\
\hline 1 output product & $20 \%$ & $0 \%$ & $0 \%$ & $20 \%$ & $0 \%$ & $0 \%$ & $0 \%$ \\
\hline 2 output products & $40 \%$ & $20 \%$ & $20 \%$ & $0 \%$ & $0 \%$ & $0 \%$ & $0 \%$ \\
\hline 3 or more output products & $20 \%$ & $40 \%$ & $0 \%$ & $0 \%$ & $0 \%$ & $0 \%$ & $0 \%$ \\
\hline Informing users & $60 \%$ & $60 \%$ & $0 \%$ & $0 \%$ & $0 \%$ & $0 \%$ & $0 \%$ \\
\hline
\end{tabular}

The results of the Availability Check give a positive impression of the availability of data on digital communication channels on the example of Germany because almost all channels are represented.

Regardless of the positive result in the category Availability Check, a closer inspection of certain categories of available data shows a low number of positive results. The example of LinkedIn, and then Instagram, shows that apart from the positive result of Availability, other data do not even exist.

Thus, these two communication channels do not contain the other observed data. Available data on the Amount of incoming raw material show that Three or more input raw material are most often listed on websites and YouTube $(60 \%)$. The Amount of output product varies in relation to the observed subcategory, which can be seen from Tab. 5 .

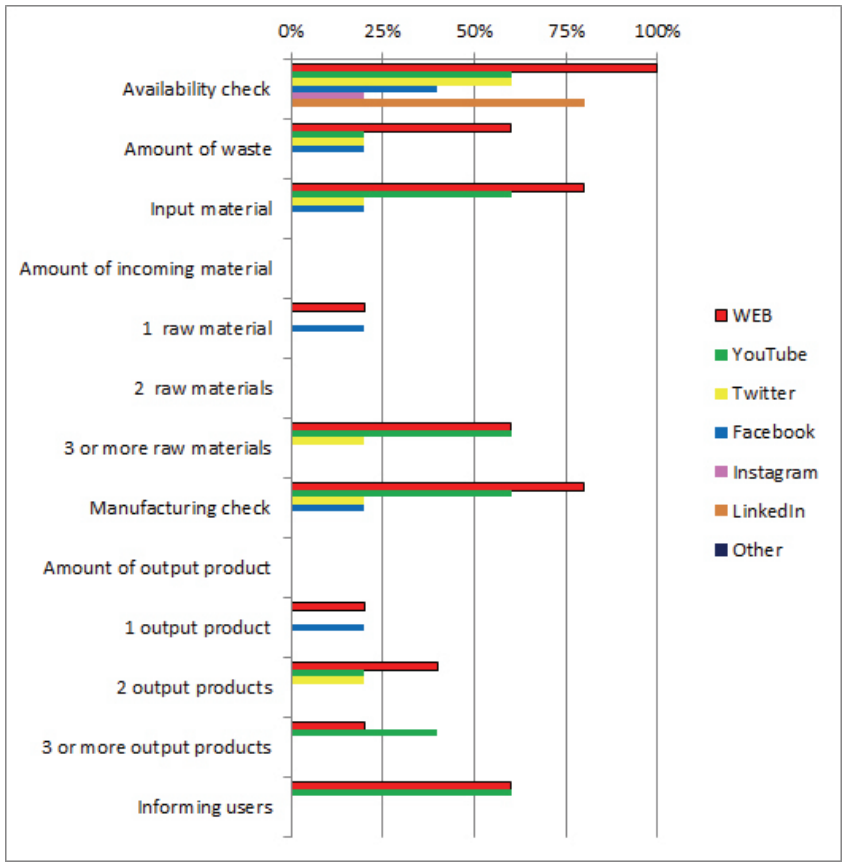

Figure 2 Graphic representation of the analysis results for Croatia

According to the graph shown in Fig. 2, it can be seen that business entities most often select the website and YouTube as a digital communication channel. Nevertheless, the website provides all the analysed data, with better availability compared to YouTube. The results of the analysis for Facebook and Twitter indicate that these communication channels are available, but to a lesser extent compared to the web and YouTube.

\subsection{Slovenia}

The analysis for Slovenia was performed on a sample of four randomly selected business entities. Tab. 6 shows that when analysing data for business entities in Slovenia, they were available on most digital communication channels, in order of percentage: websites (100\%), YouTube (50\%), and Twitter, Instagram and LinkedIn (25\%). Facebook and Other did not have a positive result.

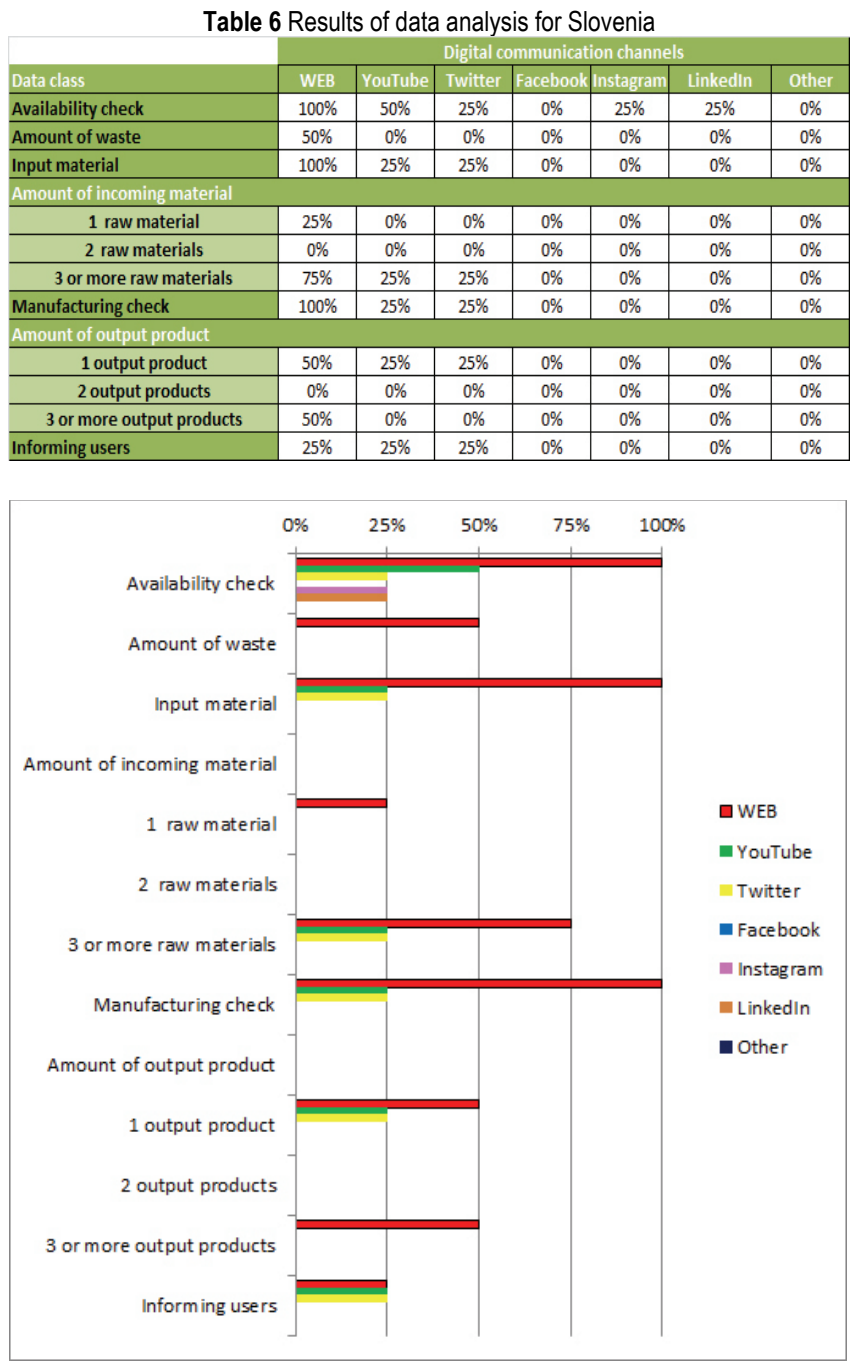

Figure 3 Graphic representation of the analysis results for Slovenia

According to the graph shown in Fig. 3, it can be seen that businesses most often use web pages. Given that all categories of data are present with an extremely high result of the availability of the website, they are also the most detailed form of information. Also, it can be seen that YouTube and Twitter are present as sources of Available data, but to a much lesser extent compared to websites. 


\subsection{Austria}

The analysis of data availability for Austria was made on a sample of five business entities randomly selected from the register. Tab. 7 shows that the results of the data availability analysis are positive in the case of the website $(100 \%)$, YouTube (60\%), Twitter and Facebook (20\%). Instagram, LinkedIn and Other digital communication channels did not have a positive result.

\begin{tabular}{|c|c|c|c|c|c|c|c|}
\hline \multirow[b]{2}{*}{ Data class } & \multicolumn{7}{|c|}{ Digital communication channels } \\
\hline & WEB & \begin{tabular}{|l|l|} 
YouTube \\
\end{tabular} & Twitter & Facebook & Instagram & Linkedlin & Other \\
\hline Availability check & $100 \%$ & $60 \%$ & $20 \%$ & $20 \%$ & $0 \%$ & $0 \%$ & $0 \%$ \\
\hline Amount of waste & $100 \%$ & $0 \%$ & $20 \%$ & $20 \%$ & $0 \%$ & $0 \%$ & $0 \%$ \\
\hline Input material & $100 \%$ & $60 \%$ & $20 \%$ & $20 \%$ & $0 \%$ & $0 \%$ & $0 \%$ \\
\hline \multicolumn{8}{|l|}{ Amount of incoming material } \\
\hline 1 raw material & $0 \%$ & $0 \%$ & $0 \%$ & $0 \%$ & $0 \%$ & $0 \%$ & $0 \%$ \\
\hline 2 raw materials & $0 \%$ & $0 \%$ & $0 \%$ & $0 \%$ & $0 \%$ & $0 \%$ & $0 \%$ \\
\hline 3 or more raw materials & $100 \%$ & $60 \%$ & $20 \%$ & $20 \%$ & $0 \%$ & $0 \%$ & $0 \%$ \\
\hline Manufacturing check & $100 \%$ & $60 \%$ & $20 \%$ & $20 \%$ & $0 \%$ & $0 \%$ & $0 \%$ \\
\hline \multicolumn{8}{|l|}{ Amount of output product } \\
\hline 1 output product & $60 \%$ & $40 \%$ & $20 \%$ & $20 \%$ & $0 \%$ & $0 \%$ & $0 \%$ \\
\hline 2 output products & $0 \%$ & $0 \%$ & $0 \%$ & $0 \%$ & $0 \%$ & $0 \%$ & $0 \%$ \\
\hline 3 or more output products & $40 \%$ & $20 \%$ & $0 \%$ & $0 \%$ & $0 \%$ & $0 \%$ & $0 \%$ \\
\hline Informing users & $40 \%$ & $60 \%$ & $0 \%$ & $0 \%$ & $0 \%$ & $0 \%$ & $0 \%$ \\
\hline
\end{tabular}

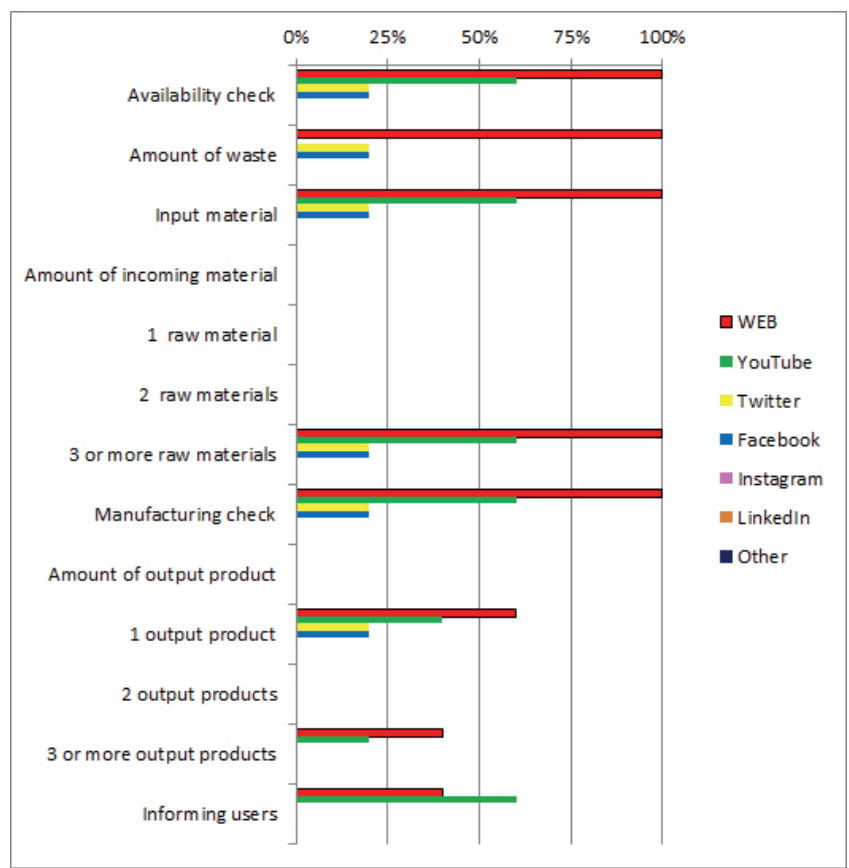

Figure 4 Graphic representation of the analysis results for Austria

According to the graph shown in Fig. 4, it can be seen that businesses in Austria most often choose websites as a source of information, and the Data availability on the websites of businesses is also the most detailed. Visible from the graph, and with reference to YouTube as a digital communication channel, only the lack of availability of data from the category of Informing users and Amount of output product can be noticed. Twitter and Facebook have equal analysis results with a lack of availability of Informing users data.

\subsection{The Netherlands}

The analysis of data availability for the Netherlands was made on a sample of five business entities randomly selected from the register. Tab. 8 shows the results of the analysis of data availability on digital communication channels, namely websites $(100 \%)$, YouTube and LinkedIn $(60 \%)$, Twitter and Others $(40 \%)$, and Facebook $(20 \%)$. The results of the analysis show that there were no positive results on Instagram within the observed criteria.

Table 8 Results of data analysis for the Netherlands

\begin{tabular}{|c|c|c|c|c|c|c|c|}
\hline \multirow[b]{2}{*}{ Data class } & \multicolumn{7}{|c|}{ Digital communication channels } \\
\hline & WEB & YouTube & Twitter & Facebook & Instagram & Linkedln & Other \\
\hline Availability check & $100 \%$ & $60 \%$ & $40 \%$ & $20 \%$ & $0 \%$ & $60 \%$ & $40 \%$ \\
\hline Amount of waste & $40 \%$ & $20 \%$ & $0 \%$ & $20 \%$ & $0 \%$ & $0 \%$ & $0 \%$ \\
\hline Input material & $100 \%$ & $60 \%$ & $0 \%$ & $20 \%$ & $0 \%$ & $20 \%$ & $40 \%$ \\
\hline \multicolumn{8}{|l|}{ Amount of incoming material } \\
\hline 1 raw material & $0 \%$ & $20 \%$ & $0 \%$ & $0 \%$ & $0 \%$ & $0 \%$ & $0 \%$ \\
\hline 2 raw materials & $0 \%$ & $0 \%$ & $0 \%$ & $0 \%$ & $0 \%$ & $0 \%$ & $0 \%$ \\
\hline 3 or more raw materials & $100 \%$ & $40 \%$ & $0 \%$ & $20 \%$ & $0 \%$ & $20 \%$ & $40 \%$ \\
\hline Manufacturing check & $100 \%$ & $60 \%$ & $0 \%$ & $20 \%$ & $0 \%$ & $0 \%$ & $20 \%$ \\
\hline \multicolumn{8}{|l|}{ Amount of output product } \\
\hline 1 output product & $40 \%$ & $20 \%$ & $0 \%$ & $20 \%$ & $0 \%$ & $0 \%$ & $20 \%$ \\
\hline 2 output products & $40 \%$ & $40 \%$ & $0 \%$ & $0 \%$ & $0 \%$ & $0 \%$ & $0 \%$ \\
\hline 3 or more output products & $20 \%$ & $0 \%$ & $0 \%$ & $0 \%$ & $0 \%$ & $0 \%$ & $0 \%$ \\
\hline Informing users & $40 \%$ & $40 \%$ & $0 \%$ & $0 \%$ & $0 \%$ & $0 \%$ & $40 \%$ \\
\hline
\end{tabular}

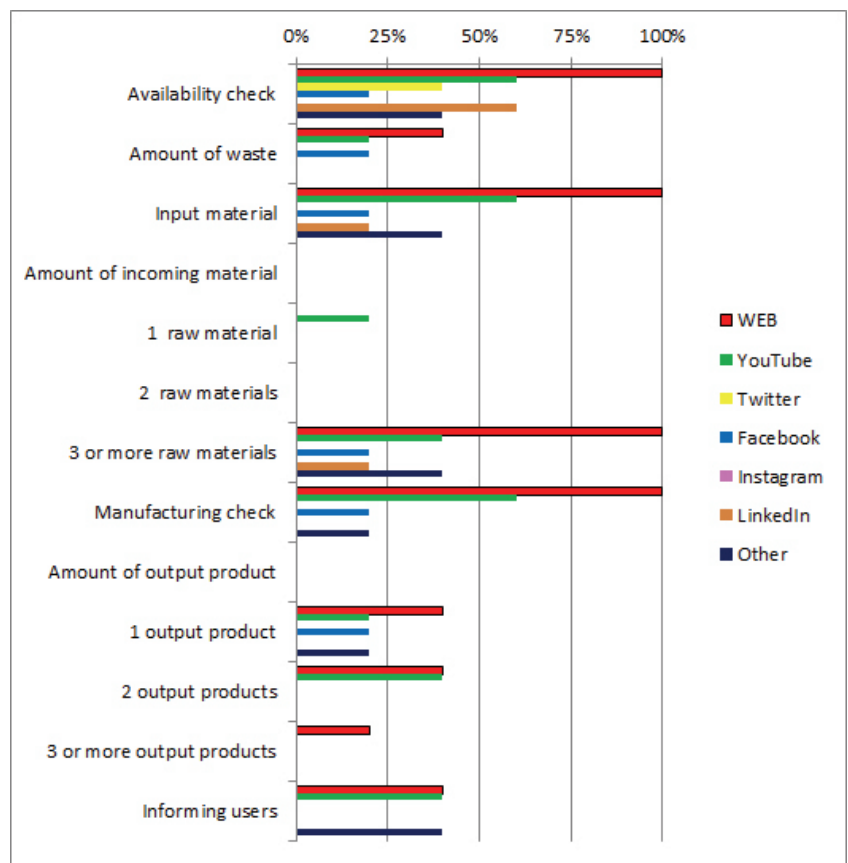

Figure 5 Graphic representation of the analysis results for the Netherlands

According to the graph shown in Fig. 5, it can be seen that for Twitter the results of the analysis are available in only one category, and that is for Availability check without additional results. The example of business entities from the Netherlands shows that websites are the main digital communication channel both in terms of the level of results and in terms of representation by category. The YouTube availability results shown in Chart 9 indicate the availability of this digital communication channel in all categories, but in a slightly lower score compared to web pages. Facebook, Instagram and Other have equal representation by category, 
with the exception that only in the case of Facebook, the analysis of the availability of the Amount of output product was positive with a result of $20 \%$.

\subsection{Belgium}

The data availability analysis for Belgium was made on a sample of two business entities randomly selected from the register. Tab. 9 shows positive results of the analysis in almost all categories of observed available data, except in the category Other, in order: websites, YouTube, Facebook, LinkedIn with $100 \%$, and Twitter and Instagram with 50\%.

Table 9 Results of data analysis for Belgium

\begin{tabular}{|c|c|c|c|c|c|c|c|}
\hline \multirow[b]{2}{*}{ Data class } & \multicolumn{7}{|c|}{ Digital communication channels } \\
\hline & WEB & YouTube & Twitter & Facebook & Instagram & Linkedln & Other \\
\hline Availability check & $100 \%$ & $100 \%$ & $50 \%$ & $100 \%$ & $50 \%$ & $100 \%$ & $0 \%$ \\
\hline Amount of waste & $100 \%$ & $50 \%$ & $50 \%$ & $50 \%$ & $0 \%$ & $0 \%$ & $0 \%$ \\
\hline Input material & $100 \%$ & $100 \%$ & $0 \%$ & $50 \%$ & $0 \%$ & $100 \%$ & $0 \%$ \\
\hline \multicolumn{8}{|l|}{ Amount of incoming material } \\
\hline 1 raw material & $0 \%$ & $0 \%$ & $0 \%$ & $0 \%$ & $0 \%$ & $0 \%$ & $0 \%$ \\
\hline 2 raw materials & $0 \%$ & $0 \%$ & $0 \%$ & $0 \%$ & $0 \%$ & $0 \%$ & $0 \%$ \\
\hline 3 or more raw materials & $100 \%$ & $100 \%$ & $0 \%$ & $50 \%$ & $0 \%$ & $100 \%$ & $0 \%$ \\
\hline Manufacturing check & $100 \%$ & $100 \%$ & $0 \%$ & $0 \%$ & $0 \%$ & $50 \%$ & $0 \%$ \\
\hline \multicolumn{8}{|l|}{ Amount of output product } \\
\hline 1 output product & $50 \%$ & $100 \%$ & $0 \%$ & $0 \%$ & $0 \%$ & $50 \%$ & $0 \%$ \\
\hline 2 output products & $50 \%$ & $0 \%$ & $0 \%$ & $0 \%$ & $0 \%$ & $0 \%$ & $0 \%$ \\
\hline 3 or more output products & $0 \%$ & $0 \%$ & $0 \%$ & $0 \%$ & $0 \%$ & $0 \%$ & $0 \%$ \\
\hline Informing users & $100 \%$ & $100 \%$ & $0 \%$ & $0 \%$ & $0 \%$ & $0 \%$ & $0 \%$ \\
\hline
\end{tabular}

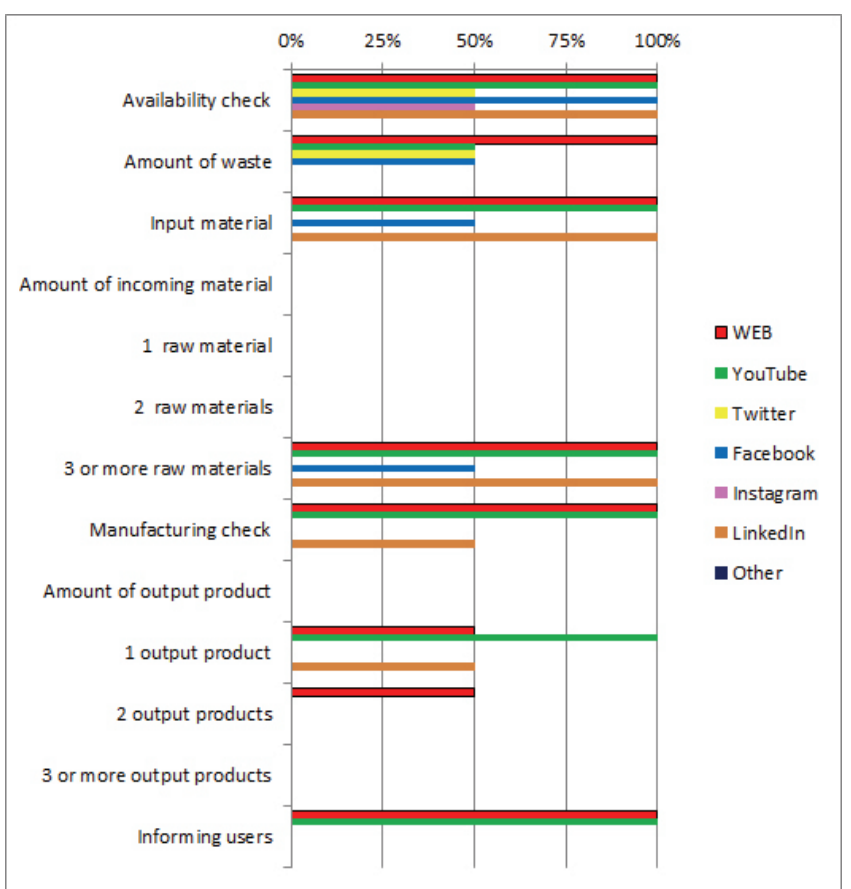

Figure 6 Graphic representation of the analysis results for Belgium

Businesses in Belgium mostly use websites as a source of Availability check of data, both by category and by detail. On the example of business entities from Belgium, it is interesting to see the increase in available data on LinkedIn, especially in the case of Input material and its Amount and Manufacturing check and results of the Amount of output product.

\subsection{Comparative Overview of Researched European Countries}

Results of the analysis of the Availability check data on the websites of business entities with regard to high results indicate that business entities most often opt for this type of digital communication.



Figure 7 Graphic representation of results for web pages by country

\section{DISCUSSION}

Website results show that Croatia has the worst result in the categories: Availability check, Amount of waste, Input material, Manufacturing check. In the category of Informing users, Croatia is in third place behind Bosnia and Herzegovina and Belgium.

The results of the analysis for YouTube show that Croatia is the worst in the categories: Availability check, Input material, Informing users. For the Amount of waste category, it is in second place behind Belgium, while for the Manufacturing check category, it shares the lowest score with Slovenia.

There is no data available for Twitter for Croatia, which makes it the worst positioned compared to other countries in all observed categories.

The results of the analysis for Facebook show that Croatia does not have positive results in data availability for the categories: Amount of waste, Input material and Informing users. Nevertheless, Croatia has the best result in the Manufacturing check category and the third result in the Availability check category behind Belgium and Germany.

The results of the analysis of Instagram as a digital communication channel show that there is no data available for Croatia and it shares the same result with Bosnia and Herzegovina, Austria and the Netherlands. Belgium, Slovenia and Germany have a better result compared to Croatia.

For LinkedIn, there is no data available neither for Croatia, nor for Bosnia and Herzegovina, which is why they share the worst result through all of the observed categories.

Insight into the results through 6 categories shows that in 6 digital communication channels Croatia has the worst result, which confirms the hypothesis of this. 


\section{CONCLUSION}

Waste, especially municipal waste, is a problem of modern civilization living in the digital age. Therefore, it is tentatively possible to assume that the use of digital communication channels can influence the environmental awareness of all stakeholders in the process of its material recovery, because digital communication channels allow rapid exchange of information on innovative communication approaches and technological solutions.

The results of the research suggest that the huge potential of currently available digital communication channels has been neglected, with the exception of the website. Achieving better availability of data on the material recovery of municipal waste is possible through the LinkedIn platform, which enables communication between business operators and users.

In addition to websites and LinkedIn, it is necessary to use the opportunities provided by other social networks, which is why it is necessary to work on increasing the use of Facebook, YouTube, Twitter, and Instagram by business entities whose activity is material recovery of municipal waste in all observed countries.

During the research, the problem of defining a set of information that is necessary to convey to the public was noticed, as well as the problem of detecting a set of feedback information from the public. Whether these sets of information correlate, whether data classes correlate with the type of digital channel, how to structure them into a standard information model - these are research questions relevant for further research with the purpose of designing a unique conceptual framework for a digital communication information set of a municipal waste material recovery service provider. In this sense, this paper represents an initiative step that can be further developed by creating additional data classes which do not appear in any of the existing information models that would include a statistically significant sample.

\section{Notice}

The paper was presented at MOTSP $2021-12^{\text {th }}$ International Conference Management of Technology - Step to Sustainable Production, which took place in Poreč/ Porenzo, Istria (Croatia), on September 8-10, 2021. The paper will not be published anywhere else.

\section{REFERENCES}

[1] Wang, S., Wang, J., Zhao, S., \& Yang, S. (2019). Information publicity and resident's waste separation behavior: An empirical study based on the norm activation model. Waste Management, 87, 33-42. https://doi.org/10.1016/j.wasman.2019.01.038

[2] Wang, Z., Guo, D., Wang, X., et al (2018). How does information publicity influence residents' behaviour intentions around e-waste recycling? Resources, Conservation and Recycling, 133, 1-9.

https://doi.org/10.1016/j.resconrec.2018.01.014
[3] Mateljak, D. (2015). Strategija odnosa s javnošću u razvoju cjelovitog sustava gospodarenja otpadom u Splitskodalmatinskoj županiji za razdoblje od 2015. - 2018. godine. http://rcco.hr/wp-content/uploads/2018/03/strategija-odnosas-javnoscu-u-razvoju-cjelovitog-sustava-gospodarenjaotpadom-u-splitsko-dalmatinskoj-zupaniji-za-razdoblje-od2015-2018-godine.pdf

[4] Tomić, T. \& Schneider, D. R. (2020) Circular economy in waste management - Socio-economic effect of changes in waste management system structure. Journal of Environmental Management, 267, 110564. https://doi.org/10.1016/j.jenvman.2020.110564

[5] Hrvatski sabor. (2013). Zakon o održivom gospodarenju otpadom. https://narodne-novine.nn.hr/clanci/sluzbeni/2013 07_94_2123.html

[6] Hrnjak-Murgić, Z. (2016). Gospodarenje polimernim otpadom, 81-86. https://www.fkit.unizg.hr/_download/ repository/Skripta-Gospodarenje-polimernim-otpadomMurgic.pdf

[7] Naughton, C. C. (2020). Will the COVID-19 pandemic change waste generation and composition? The need for more realtime waste management data and systems thinking. Resources, Conservation and Recycling, 162, 105050. https://doi.org/10.1016/j.resconrec.2020.105050

[8] Närvänen, E., Mesiranta, N., Sutinen, U.-M., \& Mattila, M. (2018). Creativity, aesthetics and ethics of food waste in social media campaigns. Journal of Cleaner Production, 195, 102110. https://doi.org/10.1016/j.jclepro.2018.05.202

[9] Vikram Bisen, P. (2009). Business communication. New Delhi: New Age International Ltd, p 40.

[10] Pasqualetti, F. \& Nanni, C. (2005). Novi mediji i digitalna kultura. Izazov odgoju. Kateheza, 27(3), 244-265. https://hrcak.srce.hr/113804 (in Croatian)

[11] Stančić, H. (2011). Načela digitalne komunikacija. In $\mathrm{N}$. Zgrljić Rotar (ed.), Zbornik radova Digitalno doba. Zadar: Sveučilište u Zadru, p 61. (in Croatian)

[12] Eshet-Alkalai, Y. (2009). Real Time Thinking in the Digital Era. In Encyclopedia of Information Science and Technology, (Chapter 514, pp 3219-3223). IGI Global.

[13] Tomić, Z. (2016). Odnosi s javnošću, teorija i praksa (II. Amended and modified edition). Zagreb: Synopsis, p 100. (in Croatian)

[14] Zgrabljić Rotar, N. (2017). Novi mediji digitalnog doba. In L. Josić (ed.), Zbornik Informacijska tehnologija i mediji. Zagreb: Hrvatski studiji Sveučilišta u Zagrebu, pp 57-67. (in Croatian)

[15] Jiang, P., Fan, Y. V., \& Klemeš, J. J. (2021). Data analytics of social media publicity to enhance household waste management. Resources, Conservation and Recycling, 164, 105146. https://doi.org/10.1016/j.resconrec.2020.105146

[16] Ministry of environment and energy (2019). Integrated Nacional Energy and Climate Plan for the Republic of Croatia for the period 2021-2030.

https://mingor.gov.hr/UserDocsImages/UPRAVA\%20ZA\%20 ENERGETIKU/Strategije,\%20planovi\%20i\%20programi/hr $\% 20$ necp/Integrated $\% 20$ Nacional $\% 20$ Energy $\% 20$ and $\% 20 \mathrm{Cli}$ mate $\% 20$ Plan $\% 20$ for $\% 20$ the $\% 20$ Republic\%20of_Croatia.pdf

[17] Schneider, D. R., Tomić, T., \& Raal, R. (2021). Economic Viability of the Deposit Refund System for Beverage Packaging Waste - Identification of Economic Drivers and System Modelling. Journal of Sustainable Development of Energy, Water and Environment Systems, 9, 1-33. https://doi.org/10.13044/j.sdewes.d9.0386

[18] Eurostat Data Browser (2019). Recycling rate of municipal waste.https://ec.europa.eu/eurostat/databrowser/view/t2020_rt 120/default/table?lang=en 
[19] ENF Recycling. (2021). Global directory of all types of recycling companies. https://www.enfrecycling.com/

[20] ENF Recycling. (2019). Plastic Recycling Plants in Germany. https://www.enfrecycling.com/directory/plastic-plant/ Germany

[21] ENF Recycling. (2019). Plastic Recycling Plants in Slovenia. https://www.enfrecycling.com/directory/plastic-plant/OtherEurope?country_id=218

[22] ENF Recycling. (2019). Plastic Recycling Plants in Austria. https:/www.enfrecycling.com/directory/plastic-plant/Austria

[22] ENF Recycling. (2019). Plastic Recycling Plants in Netherlands. https://www.enfrecycling.com/directory/plasticplant/Netherlands

[24] ENF Recycling. (2019). Plastic Recycling Plants in Belgium. https://www.enfrecycling.com/directory/plastic-plant/OtherEurope? country_id=18

\section{Authors' contacts:}

Ljerka Luić, Assoc. Prof.

University North,

Jurja Križanića 31b, 42000 Varaždin, Croatia

ljerka.luic@unin.hr

Karlovac University of Applied Sciences,

Trg J. J. Strossmayera 9, 47000 Karlovac, Croatia

ljerka.luic@vuka.hr

\section{Krešimir Labura, M.A.Sc.M.E.}

Karlovac University of Applied Sciences,

Trg J. J. Strossmayera 9, 47000 Karlovac, Croatia

kresimir.labura@gmail.com 